\title{
Clean Cities Strategic Planning White Paper: Light Duty Vehicle Fuel Economy
}

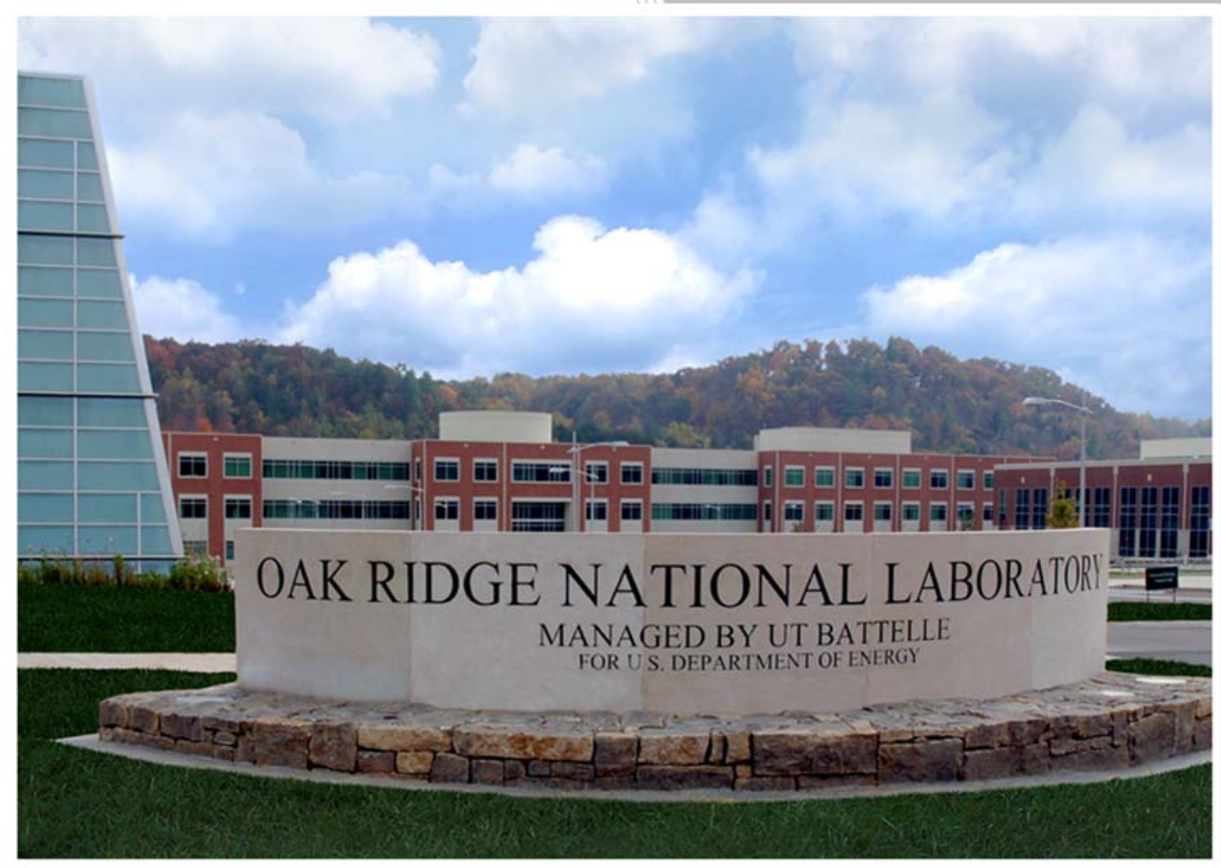

Bo Saulsbury Janet L. Hopson David L. Greene Robert Gibson

April 2015 


\title{
DOCUMENT AVAILABILITY
}

Reports produced after January 1, 1996, are generally available free via US Department of Energy (DOE) SciTech Connect.

Website http://www.osti.gov/scitech/

Reports produced before January 1, 1996, may be purchased by members of the public from the following source:

\author{
National Technical Information Service \\ 5285 Port Royal Road \\ Springfield, VA 22161 \\ Telephone 703-605-6000 (1-800-553-6847) \\ TDD 703-487-4639 \\ Fax 703-605-6900 \\ E-mail info@ntis.gov \\ Website http://www.ntis.gov/help/ordermethods.aspx
}

Reports are available to DOE employees, DOE contractors, Energy Technology Data Exchange representatives, and International Nuclear Information System representatives from the following source:

Office of Scientific and Technical Information

PO Box 62

Oak Ridge, TN 37831

Telephone 865-576-8401

Fax 865-576-5728

E-mail reports@osti.gov

Website http://www.osti.gov/contact.html

This report was prepared as an account of work sponsored by an agency of the United States Government. Neither the United States Government nor any agency thereof, nor any of their employees, makes any warranty, express or implied, or assumes any legal liability or responsibility for the accuracy, completeness, or usefulness of any information, apparatus, product, or process disclosed, or represents that its use would not infringe privately owned rights. Reference herein to any specific commercial product, process, or service by trade name, trademark, manufacturer, or otherwise, does not necessarily constitute or imply its endorsement, recommendation, or favoring by the United States Government or any agency thereof. The views and opinions of authors expressed herein do not necessarily state or reflect those of the United States Government or any agency thereof. 
Energy and Transportation Science Division

\title{
CLEAN CITIES STRATEGIC PLANNING WHITE PAPER: LIGHT-DUTY VEHICLE FUEL ECONOMY
}

\author{
Bo Saulsbury \\ Oak Ridge National Laboratory \\ Janet L. Hopson \\ David L. Greene \\ Robert Gibson \\ The University of Tennessee
}

Date Published: April 2015

\author{
Prepared by \\ OAK RIDGE NATIONAL LABORATORY \\ Oak Ridge, TN 37831-6283 \\ managed by \\ UT-BATTELLE, LLC \\ for the \\ US DEPARTMENT OF ENERGY \\ under contract DE-AC05-00OR22725
}





\section{CONTENTS}

Page

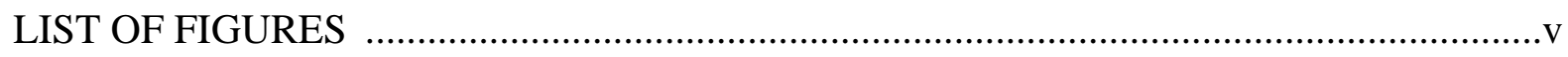

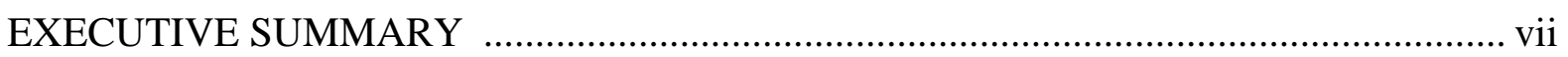

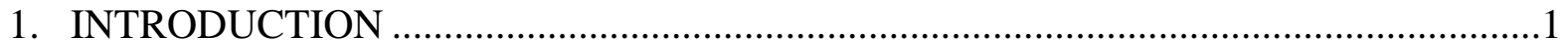

2. ISSUES AND TRENDS IN LIGHT-DUTY VEHICLE FUEL ECONOMY .......................3

3. CURRENT STATUS OF FUEL ECONOMY INFORMATION .......................................

4. RECENT RESEARCH ON FUEL ECONOMY INFORMATION AND

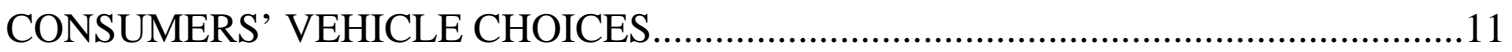

5. FEDERAL, STATE, AND LOCAL INCENTIVES..........................................................15

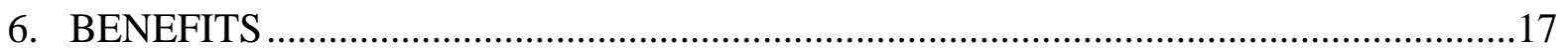

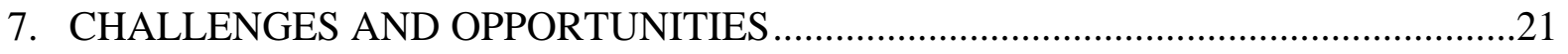

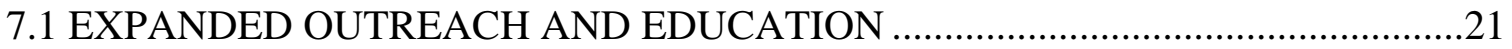

7.2 THE USED VEHICLE MARKET …………………….....................................22

7.3 CONSUMER UNCERTAINTY ABOUT OFFICIAL MPG ESTIMATES ................23

7.4 CHANGES IN HOW CONSUMERS ACCESS FUEL ECONOMY

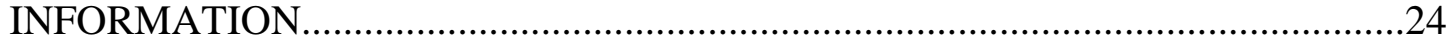

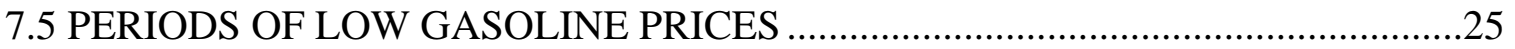

7.6 ADVANCED AUTOMOTIVE TECHNOLOGIES ...................................................27

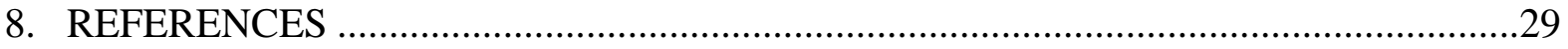





\section{LIST OF FIGURES}

Figure $\quad$ Page

$1 \quad$ Adjusted fuel economy of new light-duty vehicles by model year .......................3

$2 \quad$ Adjusted fuel economy, weight, and horsepower by model year ..........................4

$3 \quad$ U.S. light-duty fuel consumption and vehicle miles traveled ...............................5

4 User sessions hosted by www.fueleconomy.gov by model year (September-

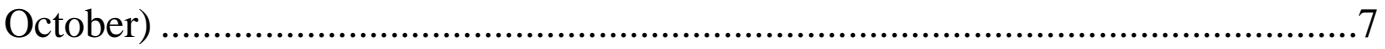

5 In-use fuel economy estimates versus EPA combined, adjusted MPG ratings for 75,000 vehicles.......................................................................................12

$6 \quad$ Monthly plug-in electric vehicle sales and number of makes and models

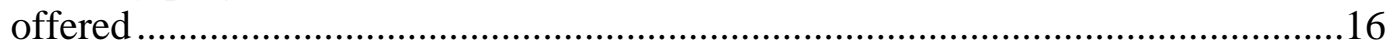

$7 \quad$ Fuel savings benefits of higher fuel economy for three midsize cars ...................18

$8 \quad$ Estimated impacts of future fuel economy standards ........................................19

9 Estimated fuel savings of the Fuel Economy Information Project ......................19

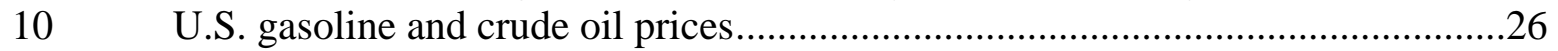





\section{EXECUTIVE SUMMARY}

Increasing the energy efficiency of motor vehicles is critical to achieving national energy goals of reduced petroleum dependence, protecting the global climate, and promoting continued economic prosperity. Even with fuel economy and greenhouse gas emissions standards and various economic incentives for clean and efficient vehicles, providing reliable and accurate fuel economy information to the public is important to achieving these goals. This white paper reviews the current status of light-duty vehicle fuel economy in the United States and the role of the Department of Energy (DOE) Clean Cities Program in disseminating fuel economy information to the public.

Overall, new light-duty vehicle fuel economy in the United States has increased since 1975, and average fuel economy increased 25\% between 2005 and 2014 (EPA 2014). This increase is likely to continue for at least the next decade because in 2012 the National Highway Transportation Safety Administration (NHTSA) and the Environmental Protection Agency (EPA) issued new Corporate Average Fuel Economy (CAFE) standards, setting the target at the equivalent of 54.5 miles per gallon (MPG) by 2025 (The White House 2012). This new standard will require model year 2025 light-duty vehicles to average about 49 MPG versus the model year 2014 combined CAFE standard of 34.1 MPG for cars and 26.3 MPG for light-duty trucks (NHTSA 2014). These new fuel economy standards will reduce future petroleum consumption in the United States significantly.

The Clean Cities Fuel Economy Information (FEI) Project fulfills DOE’s statutory responsibility to provide fuel economy information to the public in collaboration with EPA (49 USC 32908, 2006). Historically, this effort consisted of distributing to new car dealers the Gas Mileage Guide (later renamed the Fuel Economy Guide). In 1999, DOE and EPA introduced the website www.fueleconomy.gov, and it quickly eclipsed the printed Guide as a source of information for consumers.

The future poses many challenges and opportunities for Clean Cities in providing fuel economy information to the public. One essential element in providing fuel economy information is successful outreach and education. Over the next five years, the FEI Project will continue its existing outreach and education efforts, but will expand them to better coordinate with other efforts within Clean Cities. In particular, the Project will seek input from the Clean Cities Coordinators on the tools and products they need to help them convey fuel economy information to consumers, fleets, schools, and other organizations. Based on Coordinators' input, the Project will develop a "Clean Cities Fuel Economy Tool Kit" to be used by the Coordinators (and consumers, fleets, the media, schools, etc.) in outreach and educations. The Tool Kit can include existing fueleconomy.gov and Alternative Fuel Data Center (AFDC) tools, as well any new tools as they are developed. The Project can provide the Coordinators with any training and information needed for the Tool Kit. Also, the Project will continue to investigate the possibility of an Ad Council public service advertising campaign on fuel economy. Such a campaign would reach a much larger and more diverse consumer audience than any previous efforts. 
The market for used light-duty vehicles in the United States is much larger than the market for new light-duty vehicles. This presents a challenge in providing reliable fuel economy information because, unlike new vehicles, used vehicles are not required to display the new car MPG label. In addition, both buyers and sellers of used vehicles rely on a wide variety of information sources, ranging from "want ads" in local newspaper to new and used car dealerships to on-line car shopping sites. This presents an opportunity, however, because fueleconomy.gov and its most popular feature- "Find and Compare Cars"-are supported by a database of EPA fuel economy estimates for all vehicles sold in the United States since model year 1984. Along with these historic EPA fuel economy estimates, fueleconomy.gov has the "Used Car MPG Label" tool, which helps sellers advertise the original EPA fuel economy estimate for their used vehicle. Over the next five years, the FEI Project will work with the Clean Cities Coordinators to expand its outreach efforts to provide used car fuel economy data and the Used Car MPG Label tool to auto dealers and on-line car shopping sites. The Project will provide Coordinators with training and information about the Used Car MPG Label tool, and it will be included in the Fuel Economy Tool Kit.

Recent research suggests that consumers lack confidence in official fuel economy estimates. The problem appears to be that the estimates are inaccurate for many individuals even though they may be unbiased for the population as a whole. This indicates that there would be value in developing "personalized” fuel economy estimates. Over the next five years, fueleconomy.gov will develop a model to support a new "Personalized MPG Calculator" that will produce fuel economy estimates based on a driver's actual drive cycle data as recorded using on-board diagnostic (OBD) systems. When developed, this new model will support a new tool for consumers on fueleconomy.gov. In the near term, the FEI Project can provide Clean Cities Coordinators with information about data from fueleconomy.gov's "My MPG" database and research that describes how real world fuel economy varies from the EPA estimates. Eventually, the Project will provide Coordinators with training on the Personalized MPG Calculator tool and will include it in the Fuel Economy Tool Kit. The FEI Project will seek feedback from the Coordinators regarding ways to make this information, and especially the Personalized MPG Calculator, more useful to the fleets and other organizations they serve.

Since the 1970s, there have been dramatic changes in how consumers access fuel economy information. Although consumers still rely on fueleconomy.gov, they are increasingly likely to access it via mobile devices (such as tablets and smart phones) rather than personal computers. Over the next five years, the FEI Project will continue to reformat fueleconomy.gov using "responsive design” (which improves website appearance and function on all devices, especially on tablets and mobile devices). The Project will also develop mobile applications for the most popular sections of the website, starting with Finda-Car and My MPG. As consumers and fleets rely more on mobile devices to access fuel economy information, the Project will provide Clean Cities Coordinators with training and information about the tools and applications that have been developed for fueleconomy.gov, and will include the tools and applications in the Fuel Economy Tool Kit. The Project will seek feedback from the Coordinators regarding the types of information and tools they need in a mobile format. 
The Clean Cities Program faces a challenge when gasoline prices are relatively low because consumers and the media tend to pay less attention to fuel economy, and thus to the Fuel Economy Guide and fueleconomy.gov. This provides an opportunity, however, to educate consumers and the media on the cyclical nature of gasoline prices, and to stress the noneconomic benefits of fuel economy. Over the next five years, the FEI Project will work with the Clean Cities Coordinators to combine efforts to illustrate the benefits of both alternative fuels and fuel economy in a world of volatile oil prices. For example, it might be possible to use historical data on oil price volatility to construct (1) "expected" fuel prices over the lifetime of a vehicle and (2) a set of illustrative future fuel price paths that illustrate the potential for volatility. This would help demonstrate how both alternative fuels and fuel economy are likely to offer future benefits even when current oil prices are low, and also help emphasize the high energy efficiencies of options like plug-in hybrid electric vehicles. This concept could lead to new tools on fueleconomy.gov that could be included in the Fuel Economy Tool Kit and used by Coordinators to address the issue of low gasoline prices when fleets are making vehicle purchase decisions.

Hybrid electric vehicles, plug-in hybrid electric vehicles, and all-electric vehicles are becoming increasingly common in the United States, and hydrogen fuel cell vehicles are starting to enter the vehicle market in California. This presents a challenge because each of these vehicle types requires a different method of measuring fuel economy and, as vehicle technologies evolve, the effects of driver behavior and vehicle maintenance on fuel economy will change. Over the next five years, the FEI Project will continue its research to update the state of knowledge about fuel economy driving and maintenance tips, especially for advanced technology vehicles. The Project can help Clean Cities Coordinators by providing them with training and information about existing resources on fueleconomy.gov, as well as any new information or tools that are developed, and including these resources in the Fuel Economy Tool Kit. To that end, the Project will seek feedback from the Coordinators regarding the types of information and tools they need to help consumers and fleets get the best fuel economy from advanced technology vehicles. 



\section{INTRODUCTION}

Increasing the energy efficiency of motor vehicles is critical to achieving national energy goals of reduced petroleum dependence, protecting the global climate, and promoting continued economic prosperity. Even with fuel economy and greenhouse gas emissions standards and various economic incentives for clean and efficient vehicles, providing reliable and accurate fuel economy information to the public is important to the efficient functioning of the marketplace. This white paper reviews the current status of light-duty vehicle fuel economy in the United States and the role of the Department of Energy (DOE) Clean Cities Program in disseminating fuel economy information to the public. 



\section{ISSUES AND TRENDS IN LIGHT-DUTY VEHICLE FUEL ECONOMY}

Overall, new light-duty vehicle fuel economy in the United States has increased since 1975 (Figure 1). In response to the 1973 oil embargo, there was a rapid increase in fuel economy from 1975 through 1981, with average adjusted fuel economy ${ }^{1}$ increasing by 56 percent. The rate of increase slowed from 1982 through 1987, and average fuel economy actually decreased by 12 percent from 1988 through 2004. However, average fuel economy began to increase again in 2005, with a 25 percent increase between 2005 and 2014. The Environmental Protection Agency (EPA) has indicated that the preliminary model year 2014 average fuel economy is 24.2 MPG, which if achieved would be a slight increase over the model year 2013 average of 24.1 MPG (which is the current all-time record high) (EPA 2014).

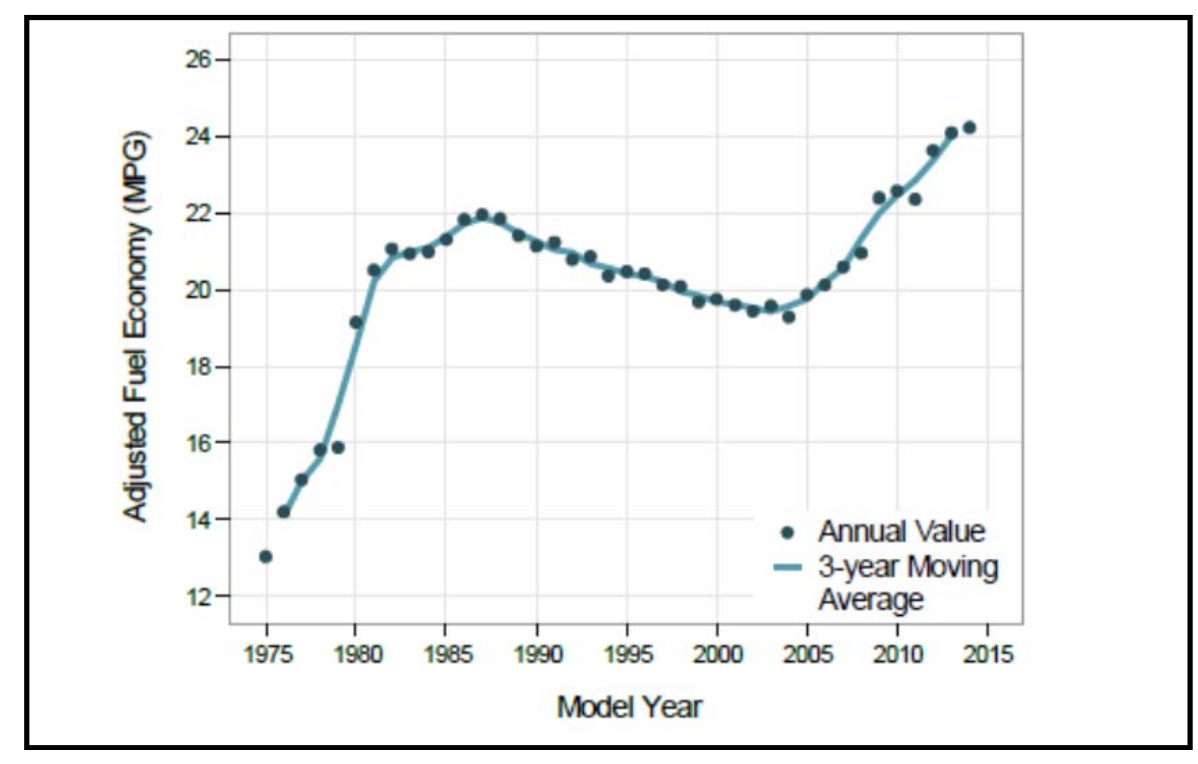

Figure 1. Adjusted fuel economy of new light-duty vehicles by model year (EPA 2014).

As indicated in Figure 2, both average vehicle weight and horsepower decreased in the late 1970s as fuel economy increased. Conversely, from the mid-1980s to 2004, average vehicle weight and horsepower increased while average fuel economy decreased. Since model year 2005, however, new automotive technology has improved both fuel economy and power, while keeping vehicle weight relatively constant. As a result, today's vehicles have greater acceleration and performance, but still have higher fuel economy (EPA 2014).

\footnotetext{
${ }^{1}$ Adjusted fuel economy values are based "on EPA's 5-cycle test methodology (reflecting urban commuting, rural highway, high speed/acceleration, high temperature/air conditioning, and cold temperature operation)" and use a " $43 \%$ city $/ 57 \%$ highway weighting in order to be consistent with the national driving activity analysis underlying the development of the 5-cycle test methodology, and yield EPA's best estimate of real-world $\mathrm{CO}_{2}$ emissions and fuel consumption” (EPA 2014).
} 


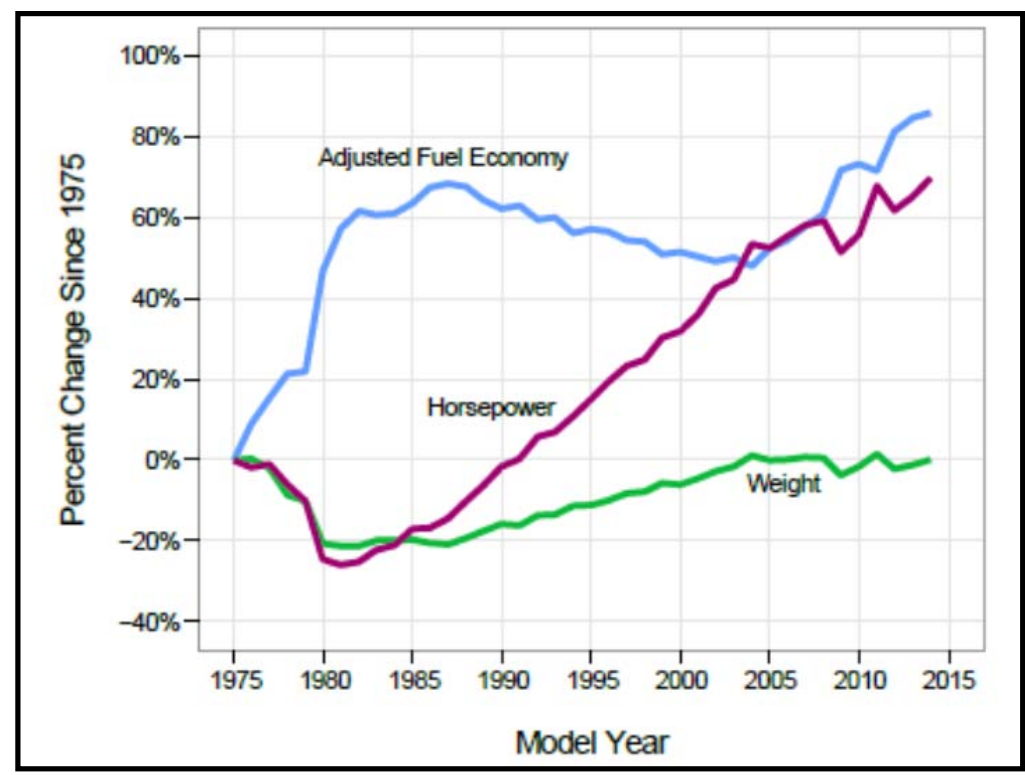

Figure 2. Adjusted fuel economy, weight, and horsepower by model year (EPA 2014).

Advances in automotive technology and resulting increases in fuel economy (particularly since model year 2005) have dramatically increased the gap between annual per capita vehicle miles traveled and annual per capita fuel use in the United States (Figure 3). Thus, the average driver today drives nearly twice as many miles as in 1970, but uses about the same amount of fuel.

The increase in average fuel economy since 1975 is likely to continue for at least the next decade. In 2012, the National Highway Transportation Safety Administration (NHTSA) and EPA issued new Corporate Average Fuel Economy (CAFE) standards ${ }^{2}$ for cars and light-duty trucks, setting the target at the equivalent of 54.5 MPG by 2025 (The White House 2012). This new fuel economy standard will require model year 2025 light-duty vehicles to average about 49 MPG versus the model year 2014 combined CAFE standard of 34.1 MPG for cars and 26.3 MPG for light-duty trucks (NHTSA 2014). Higher CAFE standards, which will result in continued technological advances in automotive design and production, will likely result in increased new vehicle fuel economy through at least 2025.

\footnotetext{
${ }^{2}$ CAFE standards are based on unadjusted, laboratory fuel economy values based on EPA's 2-cycle test methodology (reflecting urban commuting and rural highway operation only) and are weighted 55\% city/45\% highway. On average, these unadjusted fuel economy values are about $20 \%$ higher than adjusted fuel economy values (EPA 2014).
} 


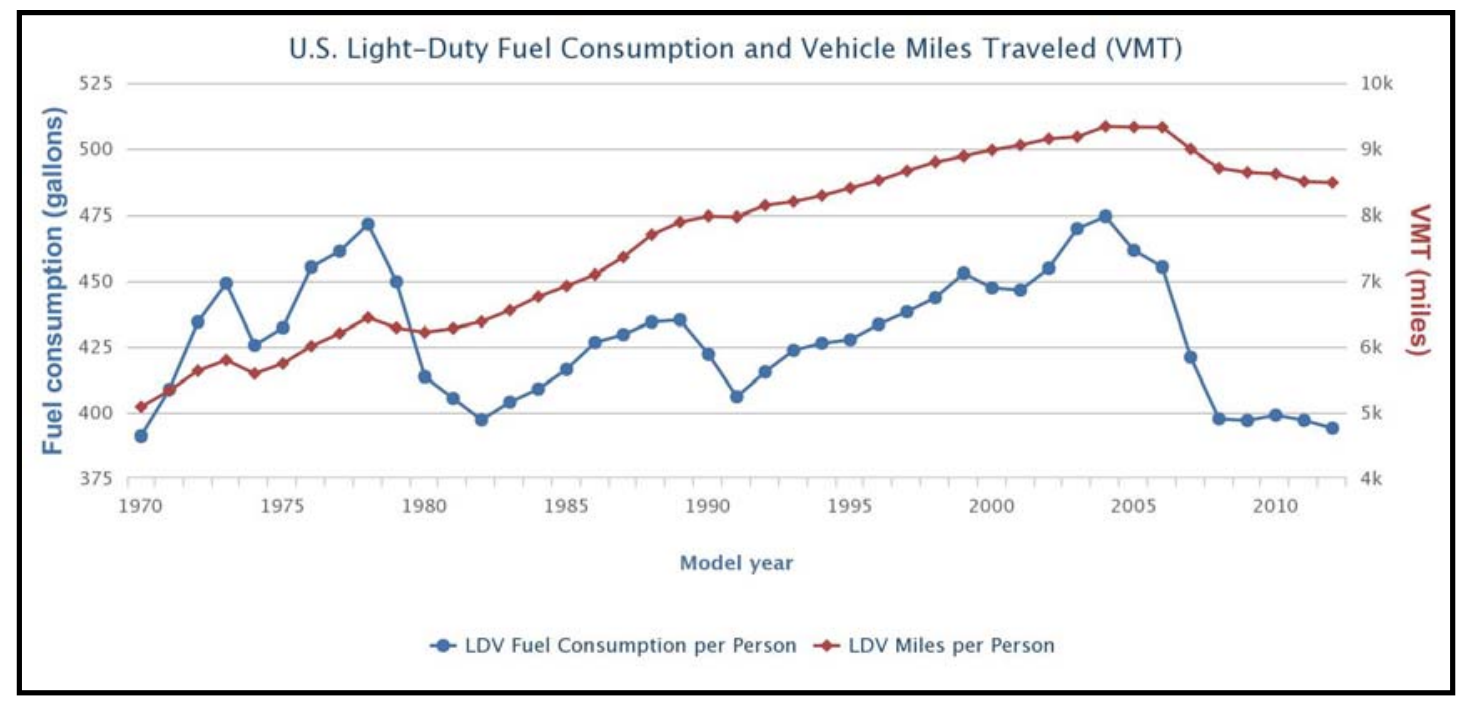

Figure 3. U.S. light-duty fuel consumption and vehicle miles traveled (AFDC 2015a).

The fuel economy improvements that have occurred since 1975 have a proven track record of reducing oil dependence while saving consumers money. For example, when applied to the total light-duty vehicle miles driven in the United States in 2012 (over 2.664 trillion vehicle miles) (AFDC 2015a), the improvement in average fuel economy from 1975 (13.1 MPG) to 2012 (23.6 MPG) (EPA 2014) saves motorists in excess of 90 billion gallons of gasoline each year, or more than $\$ 225$ billion dollars at a gasoline price of \$2.50/gallon. As a result, petroleum consumption in the United States today is more than 5.6 million barrels per day lower than it would have been at 1975 fuel economy levels. 



\section{CURRENT STATUS OF FUEL ECONOMY INFORMATION}

The Clean Cities Fuel Economy Information (FEI) Project fulfills DOE's statutory responsibility to provide fuel economy information to the public in collaboration with EPA (49 USC 32908, 2006). Historically, this effort consisted solely of compiling, publishing, and distributing to new car dealers the Gas Mileage Guide (later renamed the Fuel Economy Guide). Dealers were required to prominently display the Guide and have copies available for customers to take away.

Recognizing the rapid changes in information technology, in 1999 DOE and EPA introduced the website www.fueleconomy.gov as a new venue for disseminating fuel economy information. The website not only provides access to EPA fuel economy estimates for new vehicles, but for all light-duty vehicles back to model year 1984. The website quickly eclipsed the printed Guide as a source of information for consumers. From 400,000 user sessions ${ }^{3}$ in 1999, traffic exploded to over 58 million user sessions in 2013 (Figure 4). By contrast, the number of Fuel Economy Guides distributed for model year 2014 included 206,000 printed copies and approximately 240,000 downloads of Guides from the website. The new information technology landscape was formally recognized by a change in the requirements for fuel economy information established in a 2006 EPA rulemaking (EPA 2006a). The new rules relaxed the requirements for dealerships to distribute hard copies of the guide while emphasizing information dissemination via the internet.

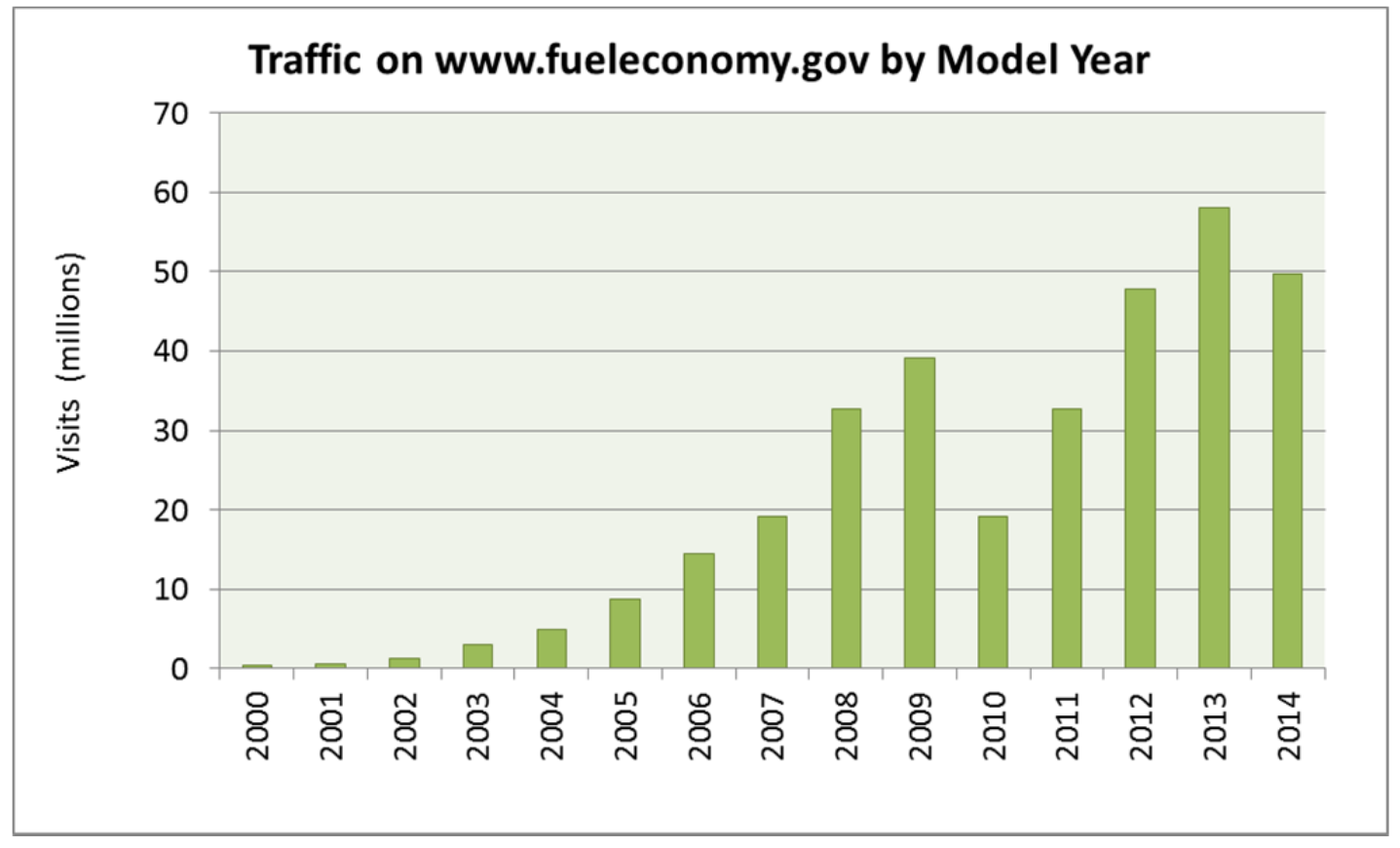

Figure 4. User sessions hosted by www.fueleconomy.gov by model year (September-October).

\footnotetext{
${ }^{3}$ One user session consists of a single a visit to the site by an individual. One user session will typically generate dozens to hundreds of hits. The average length of a user session on fueleconomy.gov has remained very nearly constant over time at about 10 minutes.
} 
Today, fuel economy information is available to consumers from a variety of sources:

- The mandatory MPG label on all new vehicles

- The annual Fuel Economy Guide

- The website fueleconomy.gov

- The mobile site fueleconomy.gov/m

- Vehicle manufacturer websites

- Other online automotive information sites such as Edmunds and Kelley Blue Book

- Newspapers and magazines such as Consumer Reports

- Television advertisements and programs

The predominant source for fuel economy estimates is EPA's certification tests. The official EPA estimates are not only used on new car labels, but in the Fuel Economy Guide, fueleconomy.gov, nearly all online automobile information websites, in manufacturers' television advertisements, and in the printed media. The only other widely available alternative estimates are Consumer Reports own mileage ratings and the publicly supplied estimates contained in the fueleconomy.gov "My MPG" database. EPA data are available for many more vehicles than either the Consumer Reports or My MPG data, and are made available in a timely manner at the beginning of and throughout each model year. As a consequence, the EPA estimates are by far the most widely used source of fuel economy information.

The EPA tests measure fuel economy under controlled conditions in a laboratory using a standardized test procedure specified by Federal law. Manufacturers test their own vehiclesusually pre-production prototypes - and report the results to EPA. EPA reviews the results and confirms about 10-15 percent of them through its own tests at the National Vehicles and Fuel Emissions Laboratory. In the laboratory, the vehicle's drive wheels are placed on a machine called a dynamometer that simulates the driving environment. The energy required to move the rollers can be adjusted to account for wind resistance and the vehicle's weight. On the dynamometer, a professional driver runs the vehicle through a standardized driving routine, or schedule, which simulates "typical" trips in the city or on the highway. Each schedule specifies the speed the vehicle must travel during each second in the test. A hose is connected to the tailpipe to collect the engine exhaust. The carbon in the exhaust is measured to calculate the amount of fuel burned during the test, which is more accurate than using a fuel gauge.

In 2008, EPA introduced new test procedures to better represent the real-world driving conditions that consumers experience. The new testing methodology combines the original city and highway tests with three new driving cycles:

1. A high-speed test that includes faster speeds and acceleration rates. The new test has a maximum speed of $80 \mathrm{mph}$ compared to the original highway test and a maximum acceleration of $8.46 \mathrm{mph} / \mathrm{sec}$, compared to $3.2 \mathrm{mph} / \mathrm{sec}$ in the original highway test.

2. A test that accounts for air conditioning use under hot outside conditions ( $95^{\circ} \mathrm{F}$ sun load) compared to the original city and highway tests which were conducted under mild conditions $\left(75^{\circ} \mathrm{F}\right)$ and without the use of air conditioning.

3. A cold-temperature test that measures the effects of colder outside temperatures $\left(20^{\circ} \mathrm{F}\right)$ on cold-start driving in stop-and-go traffic. 
The results from these new tests are used to adjust the estimates from the original city and highway tests. EPA estimates that for conventional vehicles, the new tests result in an average drop of about 10-20 percent for city MPG ratings and 5-15 percent for highway ratings. For hybrids, the new test methods should result in a 20-30 percent MPG drop compared to the old method, while highway ratings should drop by an amount similar to that for conventional vehicles (EPA 2006b). 



\section{RECENT RESEARCH ON FUEL ECONOMY INFORMATIONAND CONSUMERS' VEHICLE CHOICES}

The Clean Cities FEI Project has conducted market research and sponsored university research that has produced significant breakthroughs in our understanding of the market for fuel economy. This research is briefly reviewed below, followed by a discussion of the current understanding of the subject and implications for future Project efforts.

- In-depth survey research carried out by the University of California at Davis found that consumers typically do not make quantitative assessments of the value of improved fuel economy as economic theory would suggest (Turrentine and Kurani 2007). Although most households have estimates of their own vehicles' MPG and know the cost of a tank of gasoline, few know how much they spend on fuel in a year. None of the households in the study had ever estimated lifetime fuel savings due to MPG differences when comparing vehicles they were considering purchasing. The FEI Project is funding a follow-on study at the University of California.

- An early analysis of 3,000 in-use fuel economy data from the fueleconomy.gov MY MPG database indicated that the EPA combined city/highway fuel economy estimates, adjusted for the shortfall between test procedure values and real world experience, were very nearly unbiased estimators of fuel economy estimates reported by individuals for over 3,000 vehicles (Greene et al. 2006). The accuracy of the EPA adjusted fuel economy estimates for any particular vehicle was poor, however, with a 95\% confidence interval of +/- 7 MPG. This early finding was confirmed in a later study based on 35,000 in-use fuel economy observations (Lin and Greene 2011).

- The FEI Project is funding an update of the Lin and Greene 2011 study at the University of Tennessee using 75,000 individual fuel economy records. Preliminary analysis of these 75,000 My MPG in-use fuel economy estimates indicates that accuracy is still a large issue (Figure 5), but that the shortfall between in-use performance and EPA certification test values may be increasing. This appears to be reducing the bias of the EPA combined, adjusted fuel economy estimates for most vehicles. This research is still underway and has not been peer-reviewed, so definitive conclusions cannot be drawn at this time.

- Application of the theory of loss aversion to the market for fuel economy demonstrated that uncertainty about the value of future fuel savings combined with typical loss averse behavior was sufficient to explain consumers' apparent undervaluing of fuel economy (Greene 2011; Greene et al. 2013). This phenomenon can lead to an undervaluing of future fuel savings by a factor of two or more. The most significant source of uncertainty was not future fuel prices but rather the accuracy of official fuel economy estimates in predicting the actual fuel economy an individual would experience.

- Literature reviews of econometric estimates of consumers' willingness to pay for fuel economy found that the studies are approximately evenly divided between inferring that consumers significantly undervalue fuel savings versus valuing at discounted expected value or overvaluing (Greene 2010; Helfand and Wolverton 2011). The econometric literature provides no consensus on the subject. 


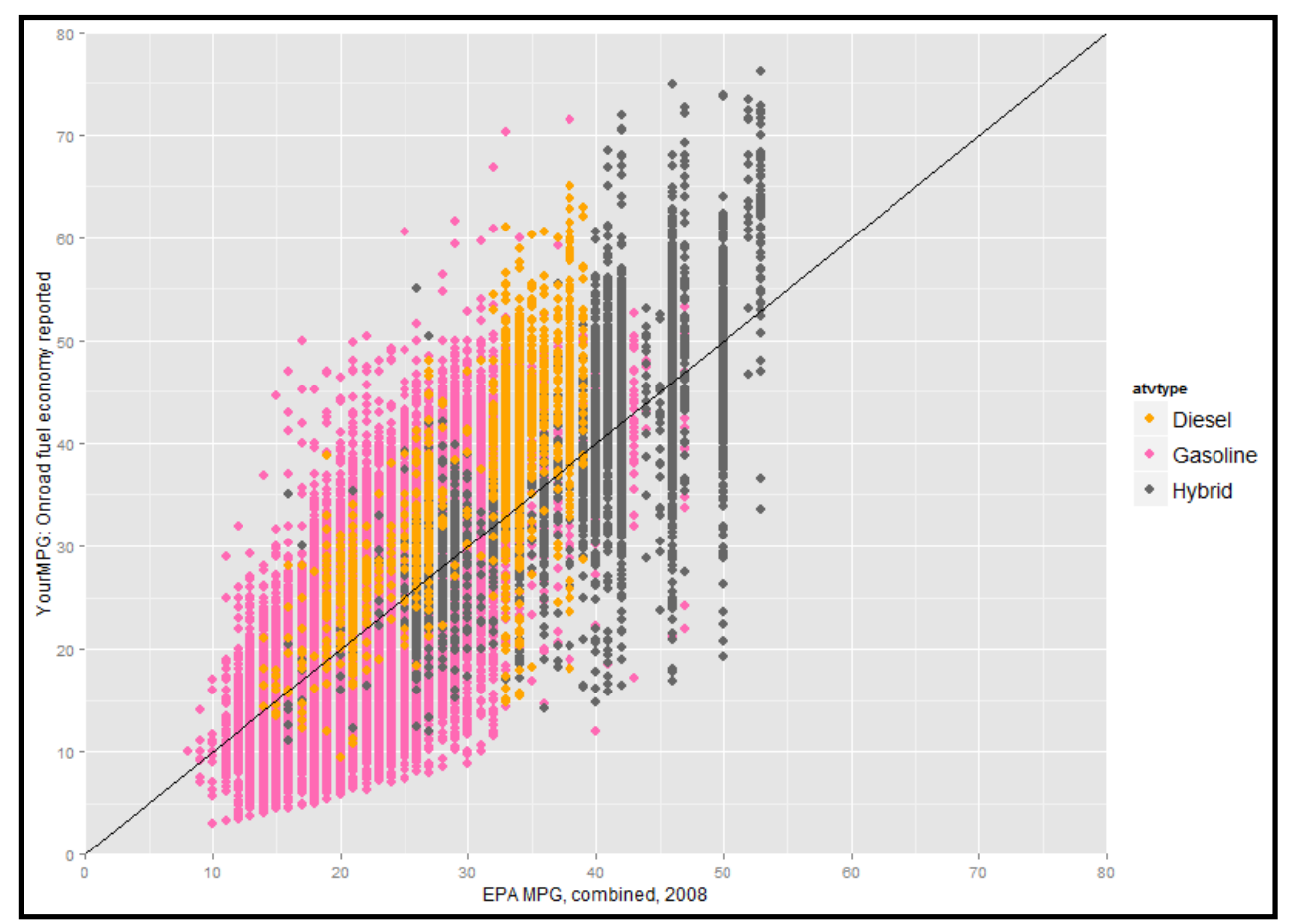

Figure 5. In-use fuel economy estimates versus EPA combined, adjusted MPG ratings for 75,000 vehicles (unpublished research in progress at The University of Tennessee).

- Automobile original equipment manufacturers have consistently stated that consumers require short payback periods of 2 to 4 years to be willing to pay for technology-based fuel economy improvements. Such short payback periods were confirmed in four nationwide household surveys covering the period 2004 to 2014 (Greene et al. 2013).

Econometric research published since the literature reviews cited above have also produced contradictory inferences. Allcott and Wozny (2012) concluded that if consumers use static expectations to predict future fuel costs they undervalue future fuel costs by about $45 \%$. In a study of consumers' choices among hybrid and non-hybrid versions of the same make and model, Gallager and Muehlegger (2011) found that consumers evaluated lifetime fuel savings using annual discount rates in excess of $40 \%$. Allcott (2012), on the other hand, concluded that consumers undervalued future fuel savings by only $12 \%$, on average.

The extant research should not be interpreted to imply that consumers do not respond to higher fuel prices by choosing more efficient vehicles. There is substantial econometric evidence that when fuel prices rise car buyers downsize, trade off performance for fuel economy, and generally pay greater attention to fuel economy in their purchase decisions (e.g., Espey and Nair 2005; Allcott and Wozny 2009; Langer and Miller 2008; Busse et al. 2013). It is possible that consumers are less uncertain about the fuel economy benefits of choosing a smaller or less powerful vehicle than about the fuel economy benefits of technologies that increase the efficiency of otherwise similar vehicles. 
Researchers at Duke University showed that consumers are confused about the relationship between fuel economy (MPG) and fuel consumption (gallons per mile), and that this contributes to inaccurate assessments of the value of fuel economy (Larrick and Soll 2008). Sallee (2013) concluded that consumers are likely to underinvest in fuel economy due to incomplete information about real-world fuel economy and future fuel prices, among other factors.

Recent research suggests that it is highly unlikely that the market for fuel economy is efficient. Application of the theory of loss aversion to consumers' choices about fuel economy rests on consumers' perception that paying more in purchase price for future fuel savings is a risky bet (Greene, German, and Delucchi 2009). Recent survey evidence confirms that consumers perceive the two most important determinants of future fuel savings-fuel economy label ratings and future fuel prices - as highly uncertain (Greene et al. 2013). All that remains to be established is that consumers are able to translate uncertainty about on-road fuel economy and future fuel prices into uncertainty about future fuel savings.

The key implication of these recent findings is that providing consumers with information that can reduce their uncertainty about future fuel savings is likely to improve market performance. In this respect, consumers would benefit more from fuel economy estimates that are more accurate for them as individuals ("personalized" fuel economy estimates) than from estimates that are less biased for the population as a whole.

In addition to suggesting the types of fuel economy information that consumers use in their vehicle purchase decisions, recent research also suggests the types of information that typically do not affect consumer decisions, particularly environmental messaging. For example, focus group research by Flamm and Agrawal (2011) concluded that "the features of vehicles currently on the market, family and work responsibilities, residential choices, and routines and preferences all constrained participants' vehicle purchase choices to ones which, more often than not, poorly reflect their environmental attitudes.” For some participants, “environmental concerns are unlikely to influence future vehicle purchase decisions, even if constraints were removed altogether; other priorities have taken and will take precedence over the environmental impacts of their choices.” Similarly, research on ecodriving behavior (Shaheen et al. 2012) found that emphasizing environmental benefits had a mixed result, at best, at encouraging more fuelefficient driving. Also, the California Center for Sustainable Energy (2013) determined that less than half of the plug-in electric vehicle drivers surveyed in California reported buying the vehicle because of environmental reasons (38\% for the Nissan Leaf, 18\% for the Chevrolet Volt, and $16 \%$ for the Toyota Prius PHEV). The key implication of these and similar research efforts is that environmental messaging is not likely to encourage consumers to purchase more fuelefficient vehicles. 



\section{FEDERAL, STATE, AND LOCAL INCENTIVES}

Federal, state, and local governments are currently promoting light-duty vehicle fuel economy and alternative fuels through a variety of incentives that reward consumers for making fuel efficient choices when purchasing a new vehicle and encourage manufacturers to develop and produce advanced, efficient vehicles. The Energy Improvement and Extension Act of 2008 established a tax credit for plug-in electric drive vehicles. This credit was later amended by the American Recovery and Reinvestment Act of 2009. The incentive is a tax credit of \$2,500 to $\$ 7,500$ for a vehicle with Gross Vehicle Weight Rating of 10,000 lbs. or less - the credit amount depends on the capacity of the vehicle's traction battery. This credit applies to qualifying vehicles purchased after December 31, 2009, and begins to phase out for a given manufacturer's vehicles after 250,000 such vehicles have been sold in the United States. Vehicle credit amounts are determined by the Internal Revenue Service, which also maintains a quarterly summary of vehicle sales by each manufacturer.

Many state and local governments also offer incentives to encourage consumers to purchase fuelefficient vehicles. State incentives include access to high occupancy vehicle (HOV) lanes, state tax credits, rebates, exemptions from vehicle excise taxes and sales taxes, and exemptions from mandatory emissions testing. Detailed information on federal and state laws and incentives is available at the Alternative Fuels Data Center (AFDC 2015b).

The federal government gives extra credits toward meeting fuel economy and greenhouse gas standards to manufacturers who sell alternative fuel vehicles. Electric and fuel cell electric vehicles, rated at zero tailpipe emissions, count as two vehicles in a manufacturer's compliance calculations starting in model year 2017, phasing down to 1.5 in 2021. Plug-in electric vehicles and compressed natural gas vehicles count as 1.6 in 2017, phasing down to 1.3 in 2021 (EPA 2012). For purposes of compliance with fuel economy standards, alternative fuel vehicles receive higher fuel economy numbers, reflecting their use of non-petroleum fuels. These incentives can be worth thousands of dollars per vehicle to manufacturers.

California's Zero Emission Vehicle (ZEV) mandates, which have been adopted by nine other states, create additional regulatory incentives for plug-in and fuel cell vehicles. The rules are complex, but essentially require manufacturers selling vehicles in California to insure that zero emission (battery electric and fuel cell electric) vehicles plus transitional zero emission (chiefly plug-in hybrid electric) vehicles amount to $4.5 \%$ of sales in 2018, rising to 22\% of sales in 2025. Battery electric vehicles generate up to $3 \mathrm{ZEV}$ credits depending on their range, while hydrogen fuel cell vehicles can produce up to $9 \mathrm{ZEV}$ credits (Morrison 2014). Because of the size of the California and Northeast U.S. vehicle markets, the ZEV mandates have been a driving force for plug-in and fuel cell vehicle technology and product development.

Together, federal, state, and local incentives and regulations have encouraged manufacturers to develop and sell plug-in electric and other alternative fuel vehicles. Since 2001, the number of plug-in electric makes and models offered in the United States and their monthly sales volumes have increased proportionately (Figure 6). Increased diversity of make and model choice is 
critical to increasing the market share of plug-in electric vehicles; a greater range of products increases the likelihood that car buyers will be able to find the product that best suits their needs and preferences.

Fueleconomy.gov helps promote alternative fuel vehicles by providing information on their economic, environmental, and energy security benefits. According to the website's "Best and Worst” ratings, the highest fuel economy passenger car in every class is a plug-in electric vehicle, except for mid-size station wagons where the Toyota Prius V takes top honors. And every class-leading plug-in electric vehicle is rated at $100 \mathrm{MPGe}$ or better. Fueleconomy.gov lists 23 plug-in electric vehicle makes and models for model year 2015, plus two hydrogen fuel cell vehicles, and provides a variety of tools for understanding the benefits of advanced, alternative fuel vehicles. For example, fueleconomy.gov's "My Plug-in Hybrid Calculator” allows consumers to estimate how much a plug-in vehicle can save on fuel based on individual driving patterns.

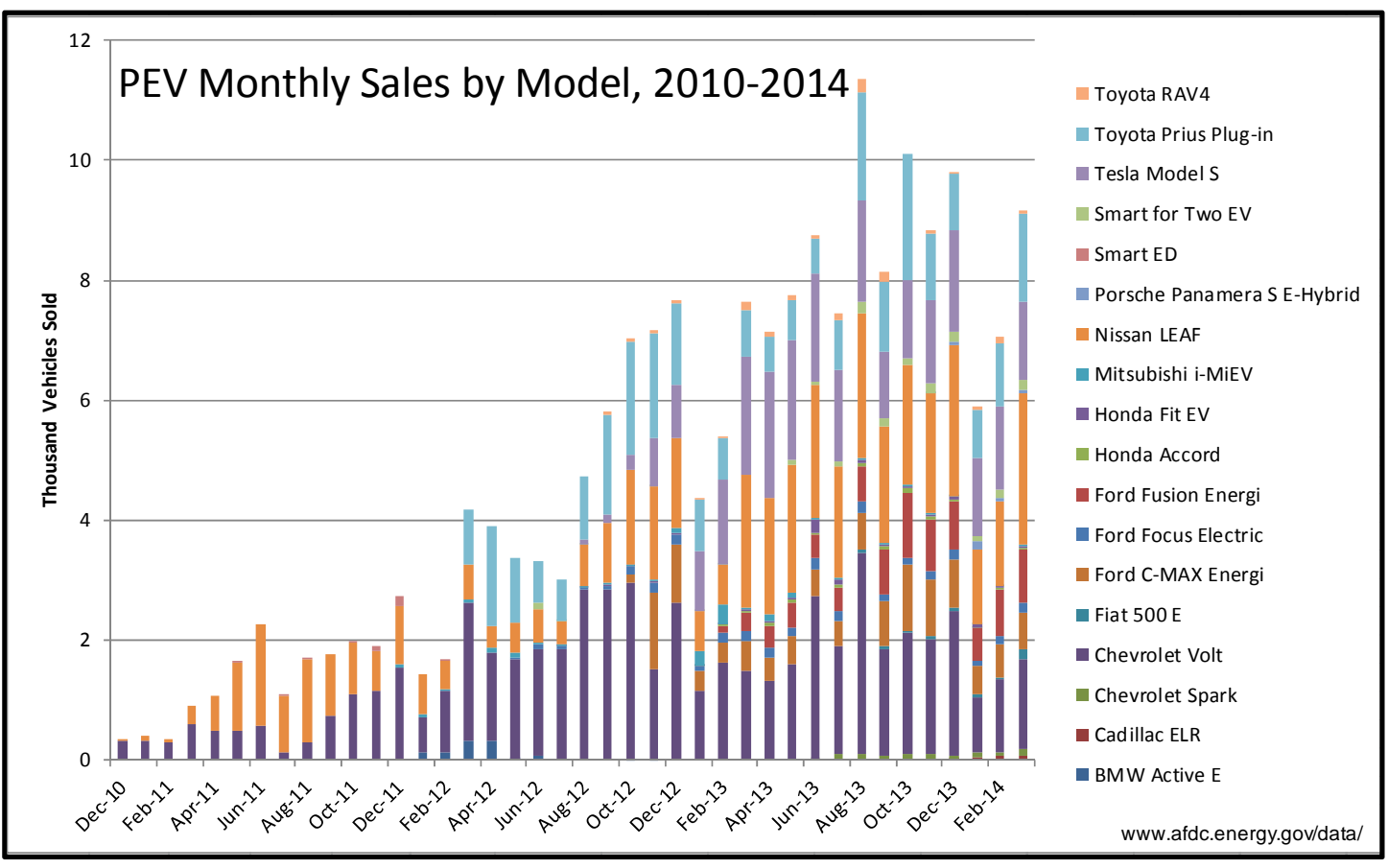

Figure 6. Monthly plug-in electric vehicle sales and number of makes and models offered (Hybridcars.com 2015; AFDC 2015b). 


\section{BENEFITS}

Improved fuel economy saves consumers money, reduces the nation's dependence on petroleum, and benefits the environment by reducing greenhouse gas emissions. The Clean Cities Program has developed several tools to help consumers and fleets estimate the benefits of fuel efficient and alternative fuel vehicles:
1) Find and Compare Cars
2) Alternative Fuel Data Center (AFDC) Cost Calculator
3) Save Money Calculator
4) Can a Hybrid Save Me Money?
5) My Plug-in Hybrid Calculator
6) What is the Speed Penalty for My Car?
7) AFDC Petroleum Reduction Planning Tool (Fleets)
8) AFleet tool
9) GREET Fleet Footprint Tool
10) Find-a-Car Mobile Application (Under Development)

Even for similar vehicles of the same size class, the money saved by choosing a more efficient vehicle can be substantial. For example, comparing model year 2015 midsize sedans using the fueleconomy.gov Find-a-Car feature, one finds that a 4-cylinder Kia Optima with an automatic transmission averages 24 MPG (Figure 7). If gasoline costs $\$ 2.35$ per gallon, the cost of fuel to drive 25 miles would be $\$ 2.45$, and total annual fuel costs for 15,000 miles of typical driving would be \$1,450. A Ford Fusion Hybrid that gets 42 MPG would cost only $\$ 1.40$ in fuel to drive 25 miles and would have an annual fuel bill of $\$ 850$ for 15,000 miles of travel. The Toyota Prius Hybrid, rated at 50 MPG, requires only \$1.18 in gasoline to go 25 miles and would require only $\$ 700$ in gasoline for 15,000 miles of driving, less than half the fuel bill of the Kia Optima. The AFDC Cost Calculator, which factors in the price of the vehicle and loan costs along with fuel costs, estimates that the Toyota Prius would save consumers more than $\$ 10,000$ over the 15-year life of the vehicle. 


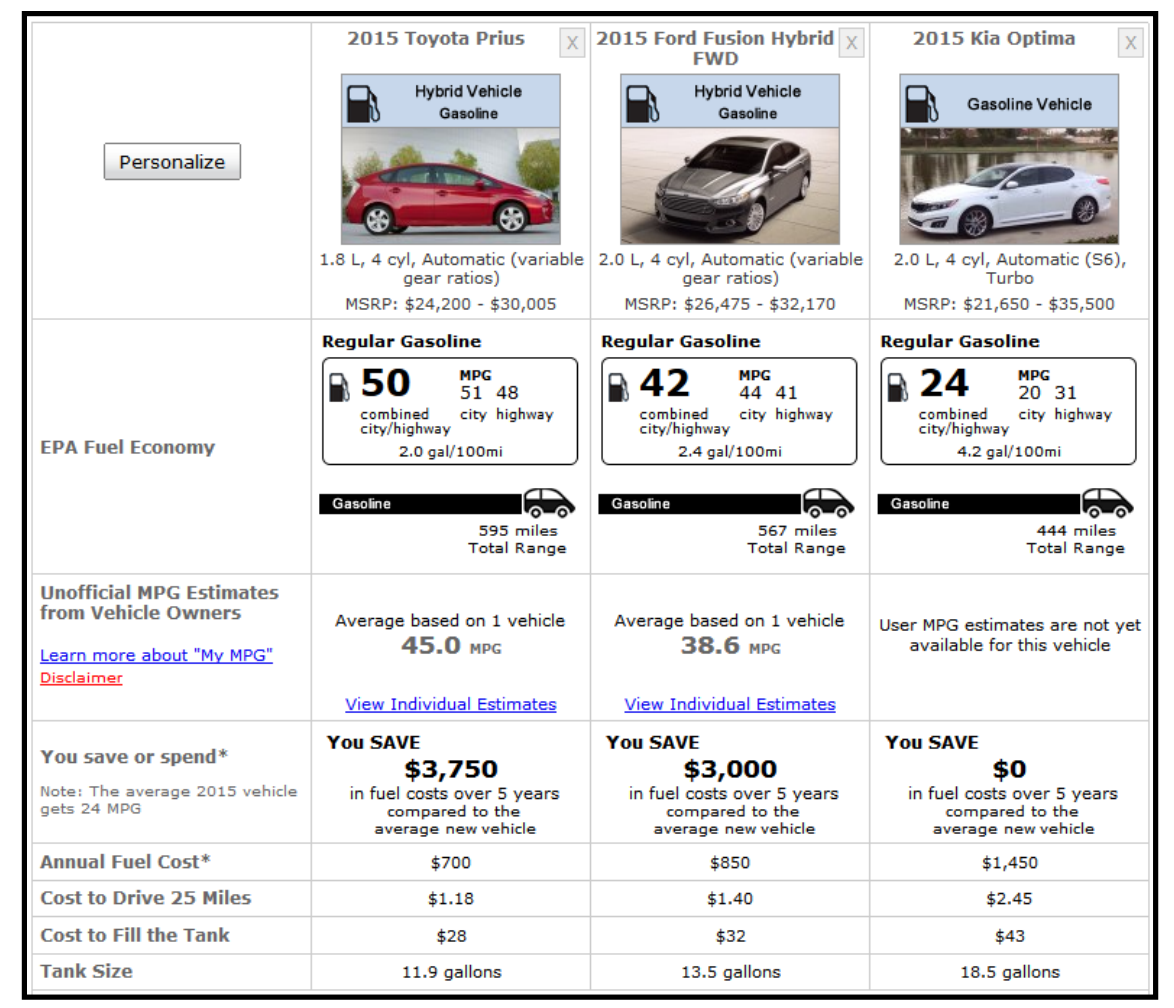

Figure 7. Fuel savings benefits of higher fuel economy for three midsize cars (annual fuel costs are rounded to the nearest \$50) (www.fueleconomy.gov).

Many consumers are attracted to hybrid and alternative fuel vehicles because of the improved gas mileage, but are reluctant to buy one because they can cost several thousand dollars more than a similarly equipped conventional vehicle. In fact, a number of media articles have argued that the fuel savings benefits offered by hybrids do not offset the increased cost of purchasing the vehicle. Fueleconomy.gov's “Can a Hybrid Save me Money” and the AFDC Cost Calculator help consumers and the media calculate these costs.

Savings are substantial at the national level, too. Just as past fuel economy improvements have saved enormous quantities of petroleum (Section 2), the fuel economy standards set for 2025 will reduce U.S. petroleum demand significantly. The more stringent fuel economy standards set by NHTSA and EPA will require model year 2025 light-duty vehicles to average about 49 MPG versus the model year 2014 combined CAFE standard of 34.1 MPG for cars and 26.3 MPG for light-duty trucks (NHTSA 2014). The Energy Information Administration (EIA) projects an increase in vehicle miles traveled (VMT) that, all else equal, would increase motor gasoline fuel consumption (EIA 2014a). However, higher fuel efficiency standards more than offset this increase in VMT, to result in an overall decline in motor gasoline consumption (Figure 8). Similarly, the EPA calculates that the more stringent fuel economy standards for model years 2012-2016 and model years 2017-2025 vehicles will save families more than \$1.7 trillion in fuel costs and reduce U.S. dependence on oil by more than 2 million barrels per day in 2025. The EPA also estimates the program will cut 6 billion metric tons of greenhouse gases over the lifetimes of the vehicles sold in model years 2012-2025 (EPA 2012). 


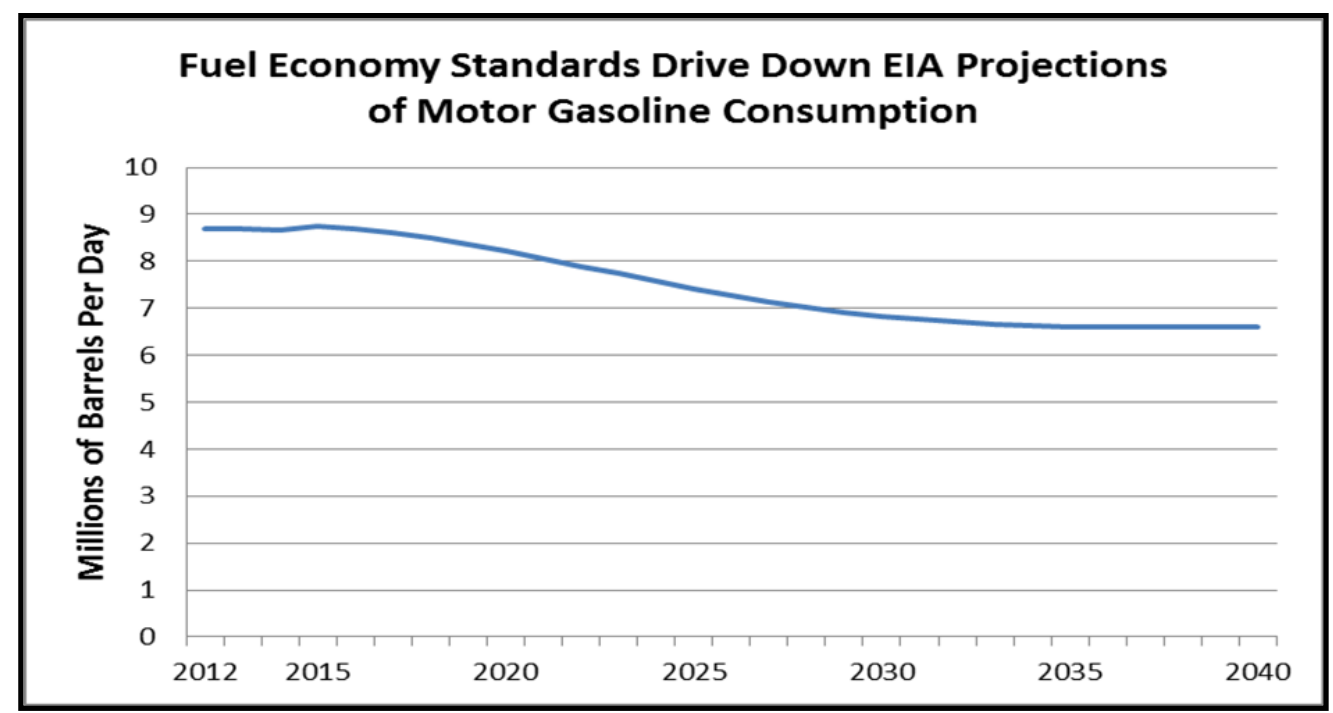

Figure 8. Estimated impacts of future fuel economy standards (EIA 2014).

The Clean Cities FEI Project has developed a method for estimating the impact of its own activities on petroleum consumption in the United States. The method begins with data on the number of visitors to fueleconomy.gov and the number of Fuel Economy Guides distributed, and supplements those data with information on media coverage of the website and Guide by television, radio, other websites and printed media. The method then applies very conservative assumptions about how use of the website and the Guide affects consumer behavior and outcomes. The method uses very conservative assumptions about consumer behavior because much of the information needed to rigorously link Project activities to real world fuel consumption is lacking or out of date. Nonetheless, using the best information available, it is estimated that the FEI Project helped consumers save over 201 million gasoline gallon equivalents (GGE) in 2013 (Figure 9).

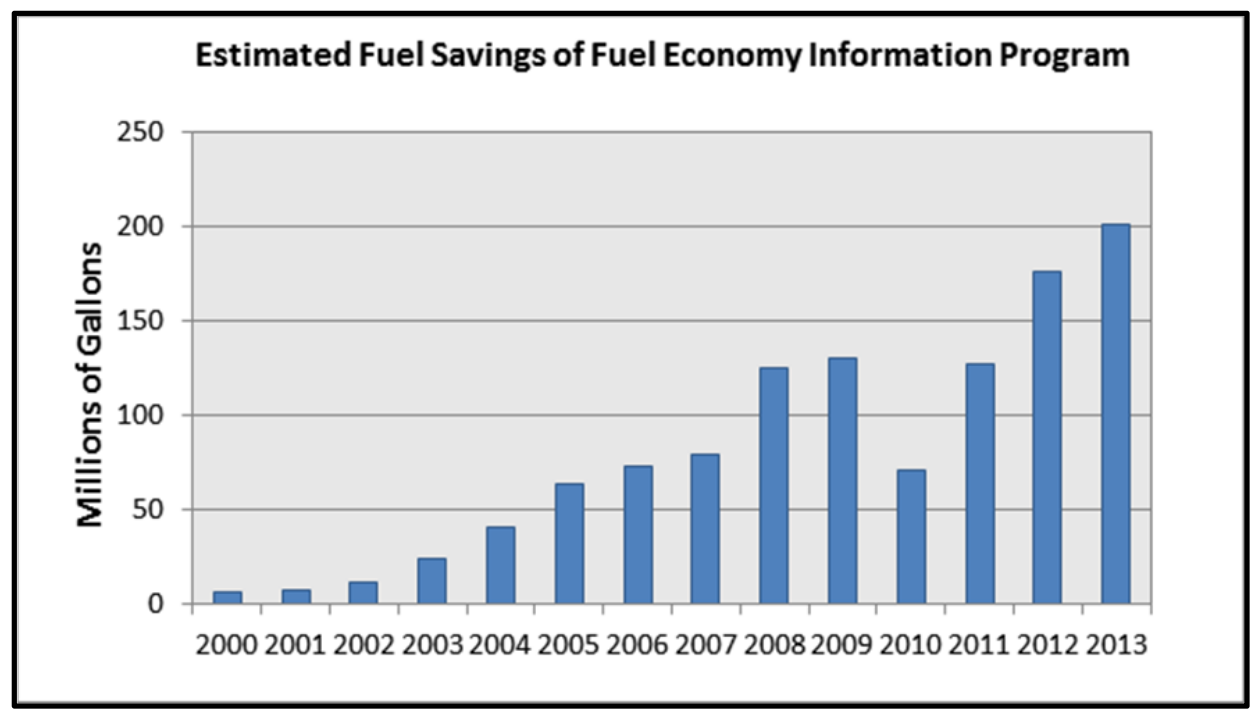

Figure 9. Estimated fuel savings of the Fuel Economy Information Project. 



\section{CHALLENGES AND OPPORTUNITIES}

The future poses many challenges and opportunities for the Clean Cities Program in providing fuel economy information to the public. The following paragraphs discuss some of the more important challenges and opportunities, as well as some existing and potential new tools, products, and partnerships the Program can use in providing fuel economy information.

\subsection{EXPANDED OUTREACH AND EDUCATION}

One essential element in providing fuel economy information has been, and will continue to be, successful outreach and education efforts. This entails developing and continually updating accurate fuel economy data and information, effectively conveying the data and information to the various interested parties, and performing outreach and education to help those parties use and further disseminate the data and information.

To date, the Clean Cities Program's most basic and successful outreach and education efforts for fuel economy have been publishing and distributing the Fuel Economy Guide and developing and maintaining fueleconomy.gov. But the outreach and education efforts have gone well beyond merely producing the Guide and the website. Since the 1970s, the Program has partnered with the National Automobile Dealers Association (NADA) to distribute and promote both the printed and the electronic Guide to all new car dealers in the United States. Since fueleconomy.gov went on-line in 1999, the FEI Project has worked to develop contacts with the media, libraries, credit unions, the American Automobile Association (AAA), on-line car shopping sites, and other organizations, and to provide them with data, information, interviews, and ideas for stories and press releases.

Since 2003, the FEI Project has partnered with the Clean Cities Coordinators on outreach and education efforts by providing them with fuel economy information, fact sheets, and other tools and by participating in regional and national Clean Cities workshops and meetings. In 2004, the Project developed and conducted the Clean Cities/Fuel Economy Partnership Program, which provided funds to six Clean Cities Coalitions to undertake innovative projects to educate the public about the benefits of fuel economy.

Clean Cities has worked with Maryland Public Television since 2004 to produce segments of the "MotorWeek" television series on fuel economy and related topics to be aired on PBS, posted on fueleconomy.gov, and used in Clean Cities outreach and education efforts. To reach Spanishspeaking populations in the United States, much of the content on fueleconomy.gov has been translated into Spanish and is available at www.ahorremosgasolina.org. More recently, the FEI Project has expanded its outreach by making the data on fueleconomy.gov and the AFDC Cost Calculator accessible to users via web services and on-line widgets. This makes it easier for developers to create web applications and mobile applications using the data. 
Over the next five years, the FEI Project will continue these existing efforts, but will expand them to better coordinate with other outreach and education efforts within the Clean Cities Program. In particular, the Project will seek input from the Clean Cities Coordinators on what tools and products they need to help them convey fuel economy information to the consumers, fleets, schools, and other organizations they serve. For example, some Coordinators have requested more information on vehicle "right-sizing" and "ecodriving” for fleets. Based on Coordinators' input, the Project will develop a “Clean Cities Fuel Economy Tool Kit” to be used by the Coordinators (and consumers, fleets, the media, schools, etc.) in outreach and education efforts. The Tool Kit can include the existing fueleconomy.gov and AFDC tools and products described elsewhere in this paper, as well as the proposed new tools and products described in the following paragraphs. The FEI Project can provide the Coordinators with any training and information needed for the tools and products in the Tool Kit.

Also, the FEI Project will continue to investigate the possibility of developing and implementing an Ad Council advertising campaign on fuel economy as an opportunity to expand outreach and education. Such a campaign would reach a much larger and more diverse consumer audience than any of the Project's previous efforts.

\subsection{THE USED VEHICLE MARKET}

The market for used light-duty vehicles in the United States is much larger than the market for new light-duty vehicles. In 2013, for example, about 42 million used vehicles were sold, compared with about 15.3 million new vehicles (Ward's Automotive 2015). This presents a challenge for the Clean Cities Program in providing reliable fuel economy information because, unlike new vehicles for sale, used vehicles for sale are not required to display the DOT/EPA new car MPG label. In addition, both buyers and sellers of used vehicles rely on a wide variety of information sources, ranging from "want ads" in local newspaper to new and used car dealerships to on-line car shopping sites. This also presents an opportunity, however, because fueleconomy.gov and its most popular feature — the "Find and Compare Cars" tool-are supported by a database of EPA fuel economy estimates for all vehicles sold in the United States since model year 1984. These historic EPA estimates provide valuable information that can help both used car buyers and sellers.

Along with EPA fuel economy estimates from model year 1984 to the present, fueleconomy.gov provides the "Used Car MPG Label" tool, which helps sellers advertise the original EPA fuel economy estimate for their used vehicle. The tool helps sellers create both an electronic fuel economy graphic that can be downloaded for on-line advertisements and a paper fuel economy label that can be printed and affixed to the vehicle's window. Both the electronic graphic and the paper label show the EPA fuel economy estimate and $\mathrm{CO}_{2}$ emissions for the vehicle when new. Because a vehicle's fuel economy changes very little over the course of a typical 15-year life, provided it is properly maintained, the original EPA fuel economy estimate remains a good indicator of a used vehicle's average gas mileage. The graphic/label also contains a Smartphone QR Code that links directly to the vehicle's information on fueleconomy.gov $/ \mathrm{m}$. This allows potential buyers to verify the information on the graphic or label and look up other data such as personalized annual fuel cost, greenhouse gas emissions, and petroleum use estimates based on 
their annual mileage, driving conditions, and fuel costs. They can also view gas mileage estimates in My MPG from other drivers with the same vehicle year, model, and configuration.

To better serve both used car buyers and sellers, over the next five years the FEI Project will work with the Clean Cities Coordinators to expand its outreach efforts to provide used car fuel economy data and the Used Car MPG Label tool to auto dealers and on-line car shopping sites. The Project will provide Coordinators with training and information about the Used Car MPG Label tool, and it can be included in the Clean Cities Fuel Economy Tool Kit.

The FEI Project has worked with representatives of NADA and the National Independent Automobile Dealers Association (NIADA) to encourage their member dealers to use the historic EPA data and the Used Car MPG Label tool. The Project has also contacted representatives from some on-line car shopping sites, including e-Bay Motors, AutoTrader.com, and CarMax.com, to arrange for their use of the EPA data and the Used Car MPG Label tool. To date, neither of these efforts has been very successful, but the Project will seek input from the Clean Cities Coordinators to help develop outreach efforts that will promote these tools to auto dealers and on-line car shopping sites. The Coordinators might be able to provide important contact information for dealers and on-line sites. The Project will also seek feedback from the Coordinators regarding ways to make this used vehicle information more useful to the fleets and other organizations they serve.

\subsection{CONSUMER UNCERTAINTY ABOUT OFFICIAL MPG ESTIMATES}

As discussed in Section 4, research suggests that consumers would give greater value to fuel economy if the uncertainty about future energy savings could be reduced. A key source of uncertainty is lack of confidence in official fuel economy estimates. The problem appears to be that the estimates are inaccurate for many individuals even though they may be unbiased for the population as a whole. This fact indicates that there would be value in developing methods for creating personalized fuel economy estimates, and this creates an opportunity for the Clean Cities Program.

The fueleconomy.gov website already allows users to personalize their vehicle, fuel price, and driving style input when calculating fuel cost and emissions estimates, but it does not allow users to calculate personalized fuel economy estimates. For example, the website's "Find and Compare Cars," "Fuel Savings Calculator," "My Trip Calculator," "My Plug-in Hybrid Calculator," and "Can a Hybrid Save me Money" sections all allow users to personalize their input. The website's My MPG feature comes closer to providing personalized MPG estimates because in addition to allowing users to personalize their vehicle, fuel price, and driving style input, it also provides "real world" MPG estimates from users with the same vehicle. In 2011, the FEI Project carried out a statistical analysis of over 25,000 My MPG records to quantify relationships between easily identifiable factors (city/highway driving, driving style, state of residence, method of measurement, vehicle drivetrain technology) and real-world fuel economy (see Section 4). The Project is now conducting a new and expanded version of that analysis, with a data set of over 75,000 My MPG records. By taking these factors into account, it should be possible to produce more accurate, personalized fuel economy estimates. 
To address the issue of consumer uncertainty about official MPG estimates, over the next five years fueleconomy.gov will develop and refine a model to support a new "Personalized MPG Calculator" that will produce fuel economy estimates based on a driver's actual measured drive cycle data. The goal of this effort is to develop a more accurate method of estimating fuel economy for specific individuals based on their driving profile as recorded in on-board diagnostic (OBD) system data. This new model, which when developed will support a new tool on fueleconomy.gov, will also enable more accurate estimates of electricity vs. gasoline use in plug-in hybrid electric vehicles and the applicability of limited range vehicles.

The FEI Project can work with Clean Cities Coordinators to address uncertainty about official MPG estimates by providing them with training and information that explains how the EPA estimates are developed. Coordinators can then disseminate that information to consumers, fleets, and the media. The Project can also provide Coordinators with training and information about data from My MPG and information from research conducted by the FEI Project that describes how real world fuel economy varies from the EPA estimates. Eventually, the Project will provide Coordinators with training on the Personalized MPG Calculator tool and will include it in the Fuel Economy Tool Kit, thereby enabling them to help the fleets they serve develop more accurate, personalized fuel economy estimates for use in comparing vehicles. The FEI Project will seek feedback from the Coordinators regarding ways to make this information, and especially the Personalized MPG Calculator, more useful to the fleets and other organizations they serve.

\subsection{CHANGES IN HOW CONSUMERS ACCESS FUEL ECONOMY INFORMATION}

Since the 1970s, there have been dramatic changes in how consumers access fuel economy information. From the mid-1970s through the 1990s, consumer access was via the print version of the Fuel Economy Guide. Beginning in 1999, consumer access via the personal computer and the website fueleconomy.gov began to eclipse use of the printed Guide. Although consumers in 2015 still rely on fueleconomy.gov, they are increasingly likely to access it via mobile devices (such as tablets and smart phones) rather than personal computers.

The website AutoTrader.com recently released the findings of its 2014 Automotive Buyer Influence Study, which examines how consumers shop for vehicles online, offline, and across multiple devices (AutoTrader.com 2014). Conducted by IHS Automotive, the study surveyed nearly 1,900 participants who had purchased a new or used light-duty vehicle within the past 12 months and who were the primary decision maker in the vehicle purchase (AutoTrader.com 2014).

The AutoTrader.com study "demonstrates how the consumer shopping process is rapidly evolving as the next generation of car buyers-Millennials - age into the largest car buying cohort” (AutoTrader.com 2014). Key findings of the study include:

- "Traditional media is aging out. Since this study was first released in 2011, there has been a precipitous decline in the use of traditional media in car shopping, with significant 
increases in the use of the Internet ... The increased use of the Internet is being led by the Millennial generation, of which 95 percent use the Internet to shop for cars.”

- "Mobile rules with Millennials. The use of multiple devices in the car shopping process has increased dramatically ... A As Millennials age into the largest car buying cohort and Boomers age out, the percent of shoppers using multiple devices to shop for cars will increase significantly — to 80 percent by the year 2020.”

- "Millennials are leading the decline in desktop/laptop usage for car shopping. Along with the precipitous increases in multi-device usage, the study is showing an initial decline in the use of desktops/laptops for car shopping among all car buyers . . . This decline was driven by the Millennial generation, who reported a nine percentage point decrease in desktop/laptop usage year-over-year, from 87 percent in 2013 to 78 percent in 2014.”

- “Half of Millennials used a smartphone to shop for a car. The study findings revealed significant increases in smartphone usage for car shopping among all car buyers ... However; the most striking use of smartphones was seen amongst the Millennial generation: 50 percent reported using a smartphone to shop for their next vehicle in 2014 . This has increased significantly since 2013, when 34 percent of Millennials used their smartphones to shop for cars.”

The results of this AutoTrader.com study emphasize the need to continually upgrade and improve fueleconomy.gov, and the need for future upgrades and improvements to address the fact that consumer access is likely to be increasingly via mobile devices (such as tablets and smart phones) rather than personal computers.

To address the issue of changes in consumer access to fuel economy information, over the next five years the FEI Project will continue to reformat fueleconomy.gov using "responsive design" (which improves website appearance and function on all devices, but especially on tablets and mobile devices). The Project will also develop mobile applications for the most popular sections of the website, starting with Find-a-Car and My MPG. As consumers and fleets begin to rely more on mobile devices to access fuel economy information, the Project will provide Clean Cities Coordinators with training and information about the tools and applications that have been developed for fueleconomy.gov to make it more accessible to mobile users, and will include the tools and applications in the Fuel Economy Tool Kit. The Project will seek feedback from the Coordinators regarding the types of information and tools they need in a mobile format to help the fleets they serve.

\subsection{PERIODS OF LOW GASOLINE PRICES}

Gasoline prices tend to be cyclical, generally rising and falling with crude oil prices. The Clean Cities Program faces a challenge when gasoline prices are relatively low because consumers and the media tend to pay less attention to fuel economy, and thus to the Fuel Economy Guide and fueleconomy.gov. Generally speaking, the number of daily user sessions on fueleconomy.gov, as 
well as the number of media stories citing fueleconomy.gov, tends to decrease with falling gasoline prices.

EIA reports that, driven largely by falling crude oil prices, weekly regular gasoline retail prices in the United States averaged \$2.14/gallon on January 12, 2015, the lowest since May 4, 2009 (EIA 2015). Further, EIA projects that regular gasoline retail prices, which averaged \$3.36/gallon in 2014, will average \$2.33/gallon in 2015 (Figure 10) (EIA 2015).

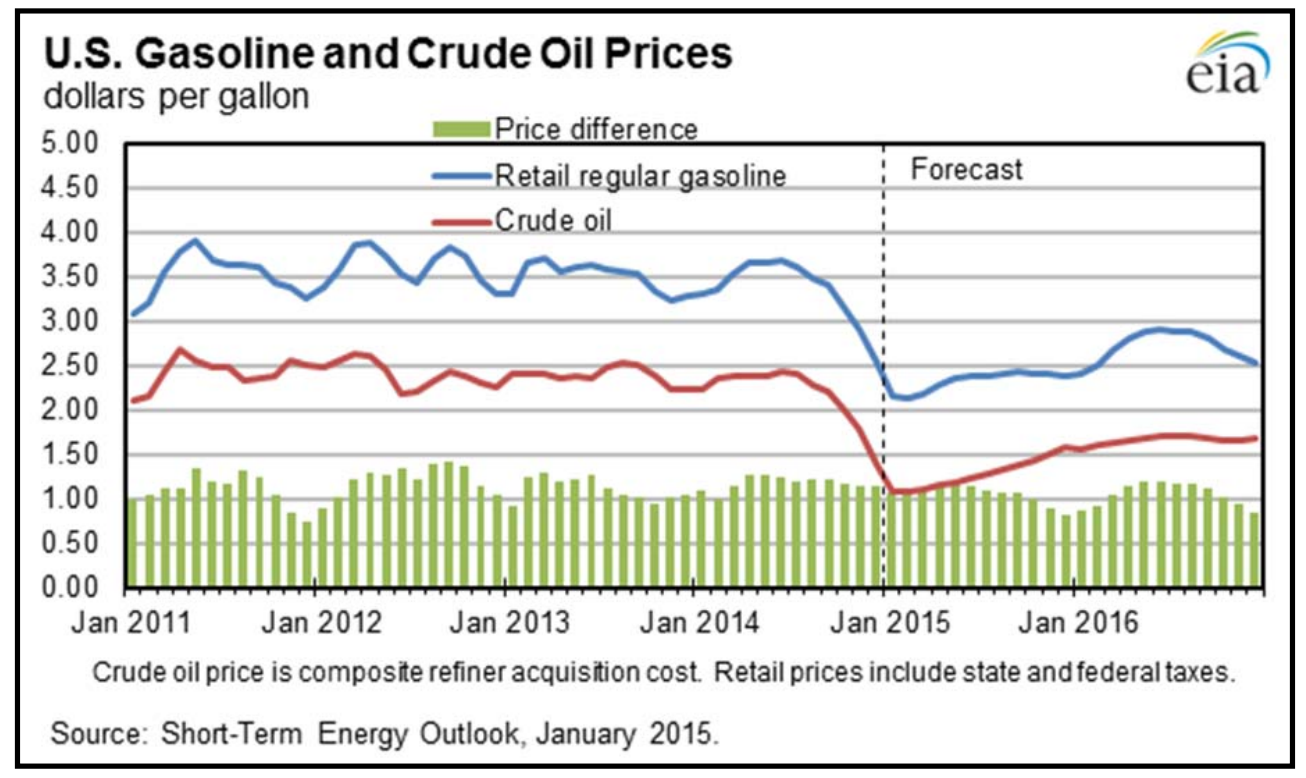

Figure 10. U.S. gasoline and crude oil prices (EIA 2015).

The challenge for Clean Cities is to continue developing strategies for disseminating fuel economy information when gasoline prices (and consumer and media interest) are low. This provides an opportunity to educate consumers and the media on the cyclical nature of gasoline prices, and to stress the non-economic benefits of fuel economy, such as reduced petroleum consumption and greenhouse gas emissions and increased energy security.

To address the issue of low gasoline prices, over the next five years the FEI Project will work with the Clean Cities Coordinators to combine efforts to illustrate the benefits of both alternative fuels and fuel economy in a world of volatile oil prices. For example, it might be possible to use historical data on oil price volatility to construct (1) "expected" fuel prices over the lifetime of a vehicle and (2) a set of illustrative future fuel price paths that illustrate the potential for volatility. This would help demonstrate how both alternative fuels and fuel economy are likely to offer future benefits even when current oil prices are low, and also help emphasize the high energy efficiencies of options like plug-in hybrid electric vehicles. This concept could lead to the development of new tools on fueleconomy.gov that could be included in the Fuel Economy Tool Kit and used by Coordinators to address the issue of low gasoline prices when fleets are making vehicle purchase decisions. 


\subsection{ADVANCED AUTOMOTIVE TECHNOLOGIES}

Hybrid electric vehicles, plug-in hybrid electric vehicles, and all-electric vehicles are becoming increasingly common in the United States, and hydrogen fuel cell vehicles are starting to enter the vehicle market in California. This presents a challenge because each of these vehicle types requires a different method of measuring fuel economy and, as vehicle technologies evolve, the effects of driver behavior and vehicle maintenance on fuel economy will change. The Clean Cities Program has the opportunity to continue its key role in helping consumers, fleets, and the media understand and interpret fuel economy estimates for these new vehicle types and get the optimal fuel economy from them.

Fueleconomy.gov already provides information and tools that help explain how advanced technology vehicles work as well as the fuel economy and economic benefits they can provide. Existing resources include the "How Hybrids Work" page and animation, the "Plug-in Hybrids" page and "How Plug-in Hybrids Save Money" animation, and the "All-Electric Vehicles" page. In the past few years, fueleconomy.gov has been updated to include fuel economy tips for plugin hybrid electric vehicles and all-electric vehicles. For purchase decisions involving advanced technology vehicles, the website provides two calculators: “Can a Hybrid Save Me Money?” and "My Plug-In Hybrid Calculator.” The website also provides some general information about flex-fuel vehicles, diesel vehicles, alternative fuel vehicles (ethanol, natural gas, and propane), and hydrogen fuel cell vehicles.

To address the issue of advanced automotive technologies, over the next five years the FEI Project will continue its research to update the state of knowledge about fuel economy driving and maintenance tips, especially for advanced technology vehicles. The Project can help Clean Cities Coordinators by providing them with training and information about existing resources on fueleconomy.gov, as well as any new information or tools that are developed, and including these resources in the Fuel Economy Tool Kit. To that end, the Project will seek feedback from the Coordinators regarding the types of information and tools they need to help consumers and fleets get the best fuel economy from advanced technology vehicles. 



\section{REFERENCES}

49 USC (U.S. Code) 32908. 2006. “Automobile Fuel Economy: Fuel Economy Information.” Title 49 U.S. Code, Sec. 32908, 2006 ed., pp. 618-619 (49 USC 32908, 2006).

AFDC (Alternative Fuels Data Center). 2015a. U.S. Light Duty Fuel Consumption and Vehicle Miles Traveled (VMT). http://www.afdc.energy.gov/data/10307.

AFDC. 2015b. "Federal and State Laws and Incentives.” http://www.afdc.energy.gov/laws.

Allcott, H. 2012. “The Welfare Effects of Misperceived Product Costs: Data and Calibrations from the Automobile Market.” American Economic Journal: Economic Policy. vol. 5, no. 3, pp. 30-66.

Allcott, H. and N. Wozny. 2009. “Gasoline Prices, Inattentive Consumers, and the Energy Paradox.” Working paper, Harvard Energy Technology Innovation Policy Group and Harvard University Center for the Environment. July 19, 2009.

Allcott, H. and N. Wozny. 2012. "Gasoline Prices, Fuel Economy and the Energy Paradox.” NBER Working Paper 18583. National Bureau of Economic Research. Cambridge, MA.

AutoTrader.com. 2014. 2014 Automotive Buyer Influence Study Demonstrates How Millennials Are Accelerating Change In Car Shopping. August 14. http://press.autotrader.com/2014-08-142014-Automotive-Buyer-Influence-Study-Demonstrates-How-Millennials-Are-AcceleratingChange-In-Car-Shopping.

Busse, M., C. Knittel, and F. Zettelmeyer. 2013. “Are Consumers Myopic? Evidence from New and Used Car Purchases.” American Economic Review. Vol. 103, no. 1, pp. 1-42.

California Center for Sustainable Energy. 2013. What Drives California's Plug-in Electric Vehicle Owners? California Plug-in Electric Vehicle Driver Survey Results.

Results of a survey conducted in May 2013 by the California Center for Sustainable Energy. http://energycenter.org/sites/default/files/infographic_pev_survey_round3_vertical.jpg.

EIA (Energy Information Administration). 2014a. "Personal Travel Growth Significantly Influences Projected Transportation Energy Demand.” Today in Energy. April 16. http://www.eia.gov/todayinenergy/detail.cfm?id=15871.

EIA. 2014b. Annual Energy Outlook 2014. May 7. http://www.eia.gov/forecasts/aeo/.

EIA. 2015. Short-Term Energy Outlook. January 13. http://www.eia.gov/forecasts/steo/. 
EPA (U.S. Environmental Protection Agency). 2006a. Fuel Economy Labeling of Motor Vehicles: Revisions to Improve Calculation of Fuel Economy Estimates. Federal Register 71 (27 December 2006): 77872-77969.

EPA. 2006b. EPA Proposes New Test Methods for Fuel Economy Window Stickers. EPA420-F06-009. Washington, DC, January. http://www.epa.gov/fueleconomy/420f06009.pdf.

EPA. 2012. EPA and NHTSA Set Standards to Reduce Greenhouse Gases and Improve Fuel Economy for Model Years 2017-2025 Cars and Light Trucks. EPA-420-F-12-051. Office of Transportation and Air Quality, Ann Arbor, Michigan. http://www.epa.gov/otaq/climate/documents/420f12051.pdf

EPA. 2014. Light-Duty Automotive Technology, Carbon Dioxide Emissions, and Fuel Economy Trends: 1975 Through 2014. EPA420-R-14-023. Office of Transportation and Air Quality, Ann Arbor, Michigan, September.

Espey, M. and S. Nair. 2005. “Automobile Fuel Economy: What is it Worth?” Contemporary Economic Policy. Vol. 23, no. 3, pp 317-323.

Flamm, Bradley and Asha Weinstein Agrawal. 2011. An Investigation into Constraints to Sustainable Vehicle Ownership: A Focus Group Study. Report CA-MTI-11-2903. Prepared by the Mineta Transportation Institute, College of Business, San José State University, California. Research sponsored by the California Department of Transportation and the U.S. Department of Transportation. http://transweb.sjsu.edu/MTIportal/research/publications/documents/2903_1008.pdf.

Gallagher, K.S. and E. Muehlegger. 2011. "Giving Green to Get Green? Incentives and Consumer Adoption of Hybrid Vehicle Technology.” Journal of Environmental Economics and Management. Vol. 61, pp. 1-15.

Greene, D.L. 2010. "How Consumers Value Fuel Economy: A Literature Review.” EPA-420R-10-008. Environmental Protection Agency, Office of Transportation and Air Quality. Ann Arbor, MI, March.

Greene, D.L. 2011. "Uncertainty, Loss Aversion and Markets for Energy Efficiency.” Energy Economics. vol. 33, pp. 608-616.

Greene, D.L., D. Evans, and J. Hiestand. 2013. "Survey Evidence on the Willingness of U.S. Consumers to Pay for Automotive Fuel Economy.” Energy Policy. vol. 61, pp. 1539-1550.

Greene, D.L., J. German, and M.A. Delucchi. 2009. "Fuel Economy: the Case for Market Failure." Chapter 11, in D. Sperling and J. Cannon, eds., Reducing Climate Impacts in the Transportation Sector. Springer Science+Business Media. 
Greene, D.L., R. Goeltz, J. Hopson, and E. Tworek. 2006. "Analysis of In-Use Fuel Economy Shortfall by Means of Voluntarily Reported Fuel Economy Estimates.” Transportation Research Record 1983. Transportation Research Board of the National Academies, pp. 99-105.

Helfand, G. and A. Wolverton. 2011. "Evaluating the Consumer Response to Fuel Economy: a Review of the Literature." International Review of Environmental and Resource Economics. vol. 5, no. 2, pp. 103-146.

Hybridcars.com. 2015. PEV Monthly Sales by Model, 2010-2014.http://hybridcars.com/marketdashboard.html.

Langer, A., N. Miller. 2008. “Automobile Prices, Gasoline Prices, and Consumer Demand for Fuel Economy.” Economic Analysis Group Discussion Paper, Department of Economics, University of California, Berkeley.

Larrick, R.P. and J.B. Soll. 2008. “The MPG Illusion.” Science. Vol. 320, pp. 1593-1594.

Lin, Z. and D.L. Greene. 2011. "Predicting Individual On-road Fuel Economy Using Simple Consumer and Vehicle Attributes.” SAE Technical Paper Series No. 11SDP-0014. Society of Automotive Engineers, Warrendale, PA, April 12.

Morrison, J. 2014. “The California Zero Emission Vehicle Mandate: Legal and Market Expectations Intertwined.” Presentation to the National Association of Motor Vehicle Boards and Commissions, Auto Advisory Services, Inc. Tustin, California. http://namvbc.org/presentations/san-diego-2014/ZEV\%20Mandate\%20Presentation.pdf .

NHTSA (National Highway Traffic Safety Administration). 2014. Summary of Fuel Economy Performance. U.S. Department of Transportation. June 26.

file://C:/Users/s51/Downloads/June_2014_Summary_Report.pdf.

Sallee, J.M. 2013. “Rational Inattention and Energy Efficiency.” Working Paper 19545, National Bureau of Economic Research, Cambridge, MA. October.

Shaheen, Susan A., Elliot W. Martin, and Rachel S. Finson. 2012. Ecodriving and Carbon Footprinting: Understanding How Public Education Can Result in Reduced Greenhouse Gas Emissions and Fuel Use. Report CA-MTI-12-2808. Prepared by the Mineta Transportation Institute, College of Business, San José State University, California. Research sponsored by the California Department of Transportation and the U.S. Department of Transportation. http://transweb.sjsu.edu/PDFs/research/2808-ecodriving-greenhouse-gas-emissions-fuel-usepublic-education.pdf.

Turrentine, T.S. and K.S. Kurani. 2007. “Car Buyers and Fuel Economy.” Energy Policy, vol. 35, pp. 1213-1223.

Ward’s Automotive. 2015. Ward's Automotive Data Center. http://wardsauto.com/. 
The White House. 2012. Obama Administration Finalizes Historic 54.5 MPG Fuel Efficiency Standards. August 28. http://www.whitehouse.gov/the-press-office/2012/08/28/obamaadministration-finalizes-historic-545-mpg-fuel-efficiency-standard. 